\title{
First report of bullet wood (Mimusops elengi) sudden decline disease caused by Ceratocystis manginecans in Indonesia
}

\author{
R. PRATAMA ${ }^{\mathbf{1}}$, A. MUSLIM ${ }^{2, \boldsymbol{v}}$, S. SUWANDI ${ }^{2}$, N. DAMIRI ${ }^{2}$, S. SOLEHA ${ }^{\mathbf{1}}$ \\ ${ }^{1}$ Agriculture Sciences Graduate Program, Faculty of Agriculture, Universitas Sriwijaya. Jl. Padang Selasa No. 524, Bukit Besar, Palembang 30139, South \\ Sumatra, Indonesia \\ ${ }^{2}$ Laboratory of Phytopathology, Department of Plant Protection, Faculty of Agriculture, Universitas Sriwijaya. Jl. Raya Palembang-Prabumulih Km 32, \\ Indralaya, Ogan Ilir 30662, South Sumatra, Indonesia. Tel.: +62-711-580663, Fax.: +62-711-580276, "email: a_muslim@unsri.ac.id, \\ rahmatpratama@pps.unsri.ac.id
}

Manuscript received: 14 January 2021. Revision accepted: 18 April 2021.

\begin{abstract}
Pratama R, Muslim A, Suwandi S, Damiri N, Soleha S. 2021. First report of bullet wood (Mimusops elengi) sudden decline disease caused by Ceratocystis manginecans in Indonesia. Biodiversitas 22: 2636-2645. Ceratocystis manginecans cause wilt and death of plants in several important crops and native vegetation in Indonesia. Ceratocystis wilt was recently found to be causing substantial mortality in bullet wood (Mimusops elengi) in South Sumatra. The aim of this study was to describe the symptomatology of the new disease and characterize isolates of $C$. manginecans obtained from diseased bullet wood plants. Diseased plants showed substantial discoloration of the woody xylem and wilt-type symptoms of the foliage, with the eventual death of the whole plant. Isolations from infected plants yielded fungi that were similar morphologically to C. manginecans, with typical hat-shaped ascospores and light-colored perithecial bases. Sequencing of the internal transcribed spacer (ITS) and $\beta$-tubulin of the isolates confirmed their identification, grouping them with $C$. manginecans and separating them from all other Ceratocystis species. This is the first report of $C$. manginecans in Indonesia causing wilt and death on bullet wood. C. manginecans is an important pathogen, and strategies to reduce losses need to be established in Indonesia because the aggressiveness of $C$. manginecans to bullet wood has been shown in inoculation experiments
\end{abstract}

Keywords: Ceratocystidaceae, molecular phylogeny, pathogenicity, Sapotaceae

\section{INTRODUCTION}

Bullet wood (Mimusops elengi) belongs to the family Sapotaceae, common English names are Asian Bulletwood, Bullet Wood Tree, Indian Medlar, Red Coondoo Spanish Cherry and it is known in Indonesia as Tanjung. The species is native to India, Sri Lanka, the Andaman Islands, Myanmar, Indo-China, Peninsular Malaysia and Vanuatu; it has been introduced and cultivated elsewhere. M. elengi can grow in tropical and subtropical climates. This plant thrives in areas with high humidity and seasonal rainfall and seasonal dry periods (Lim 2012). The bullet wood trees range from small to large, and are found in all parts of Indonesia where bullet wood is cultivated in gardens as an ornamental tree, for medicines and planted along avenues because of its fragrant flowers (Seth 2003).

$M$. elengi is widely used for medicine, and various parts of $M$. elengi Linn. (Sapotaceae) have been used widely in traditional Indian medicine for the treatment of pain, inflammation and wounds. M. elengi stem bark would be a possible therapeutic candidate having cytotoxic and antitumor potential (Kumar et al. 2016); it also has antibacterial and antifungal uses (Ali et al. 2008). At present, M. elengi is used as the synthesis of calcium phosphate nanoparticles that is easy, eco-friendly and scalable (Pokale et al. 2014).

Several types of pathogenic fungi have been identified to cause disease in $M$. elengi plants. Curvularia lunata caused die-back in India (Khatun et al. 2011);
Pestalotiopsis clavispora caused leaf blight (Lokesh et al. 2017). Ceratocystis was first isolated from a single tree of bullet wood showing sudden decline in Thailand. Symptoms displayed by the diseased trees include gum exudation from the trunks and wilting and loss of the dark green foliage with a corresponding browning of leaves on single branches. In this study they did not confirm the pathogen with a Koch postulates test detail (Pornsuriya and Sunpapao 2015). Recently we have observed many bullet wood trees showing similar symptoms with $C$. manginecans decline in many locations in South Sumatra, Indonesia.

Ceratocystis manginecans include many economically important plant pathogens. This pathogen has caused a sudden decline and has led to the death of thousands of Mangifera indica trees in Oman with Hypocryphalus mangifera vector (Al Adawi et al. 2013). In Indonesia, $C$. manginecans caused die-back on Acacia mangium and A. crassicarpa plantations in Riau (Tarigan et al. 2010), whereas in Vietnam recently, C. manginecans caused wilt disease in Dalbergia tonkinensis and Chukrasia tabularis (Chi et al. 2019a; Chi et al. 2020); in Pakistan, this pathogen also causes wilt disease in Albizia lebbeck (Razzaq et al. 2020). Commonly C. manginecans cause yellowing of leaves and rapid wilting of leaves was observed on individual branches in affected trees that ultimately spread to the canopy followed by the death of the whole tree. Dark brown to black tissue discoloration was observed in the woody xylem tissues of infected trees. 
This study aimed to identify the cause of a new outbreak of wilt disease causing a sudden decline to the trees, wilted canopies, and tree death in M. elengi in South Sumatera, Indonesia. This study was also conducted to describe the characteristics of the pathogen and confirm Koch's postulates test.

\section{MATERIALS AND METHODS}

\section{Disease symptoms and specimen collection}

The distribution and impact of the $C$. manginecans disease on $M$. elengi were determined from roadside trees planting in Jakabaring (Palembang) and Kayuagung (Ogan Komering Ilir) and the agricultural field of Sriwijaya University in Indralaya (Ogan Ilir), South Sumatra, Indonesia. Symptoms of wilt diseases were evaluated as follows: the extent of lesion development from discoloration of bark and wood, the extent of foliar wilting or loss and tree death.

Samples of diseased trunks were collected from two to six-year-old trees from September 2019 to April 2020. Wood samples were taken from lesions of wilted trees using a knife sterilized in $70 \%$ ethanol. The wood samples collected from $M$. elengi showed brown to black streaking in the woody xylem. Each sample was wrapped in tissue paper and placed in a coolbox. The same day, the wood samples (1-20 mm length, 1-2 mm thick) were sandwiched between two slices of fresh carrot and placed on sterile dry paper in plastic boxes at $25^{\circ} \mathrm{C}$ following the method of $\mathrm{Li}$ et al. (2014). After 5-10 days, hat-shaped spores of putative Ceratocystis pathogens were placed on $2 \%(\mathrm{w} / \mathrm{v})$ malt extract agar (MEA) (Merck, Germany), and incubated at 25 ${ }^{\circ} \mathrm{C}$ in a laboratory. When cultures had grown to several $\mathrm{cm}$ in diameter, hyphal tips were sub-cultured onto new MEA and potato dextrose agar (PDA) (Merck, Germany) plates and incubated at $25-28{ }^{\circ} \mathrm{C}$. Morphological traits of fruiting bodies and spores were observed under an optical Olympus CX33 microscope (Olympus Corporation, Japan).

\section{Genomic DNA extraction, PCR amplification, and sequencing}

DNA isolation used YeaStar Genomic DNA Kit (Zymo Research Corporation, California, USA). To extract genomic DNA, cultures were incubated for five days to allow sufficient mycelial growth in potato dextrose broth (PDB) (Merck, Germany). Mycelium was purified with sterile filter paper (Whatman) and transferred to $1.5 \mathrm{~mL}$ Eppendorf tubes. The quantity and quality of DNA extracted were evaluated with a spectrophotometer (NanoDrop ND-1000; Thermo Fisher, Waltham, MA, USA) to calibrate the concentration and purity of DNA as PCR templates.

The PCR amplification reactions were conducted on a T-100 thermal cycler (Bio-Rad, Hercules, CA, USA). Amplifications were carried out in $50 \mu \mathrm{l}$ reactions containing $20 \mu \mathrm{l}$ DreamTaq Green PCR Master Mix (Eppendorf, Germany) (DreamTaq DNA Polymerase, 2X DreamTaq Green buffer, dNTPs, and $4 \mathrm{mM} \mathrm{MgCl}_{2}$ ), 1,5 $\mu \mathrm{l}$ of each forward and reverse primer, $4 \mu \mathrm{l}$ of DNA template and $23 \mu \mathrm{l}$ sterilized water. The PCRs were performed with a C1000 Touch ${ }^{\mathrm{TM}}$ thermal cycler (Bio-Rad, USA). The PCR cycling parameters were as follows: initial denaturation for $5 \mathrm{~min}$ at $95^{\circ} \mathrm{C}$, followed by 35 cycles at $95^{\circ} \mathrm{C}$ for $30 \mathrm{~s}, 56^{\circ} \mathrm{C}$ for $45 \mathrm{~s}$ and $72^{\circ} \mathrm{C}$ for $1 \mathrm{~min}$. Amplification was completed at $72^{\circ} \mathrm{C}$ for $10 \mathrm{~min}$ and the PCR product was stored at $10^{\circ} \mathrm{C}$ (Chi et al. 2020).

PCR amplifications were made for two gene regions, including part of the b-tubulin (BT) using primers $\beta$ tla (TTCCCCCGTCTCCACTTCTTCATG) and $\beta \mathrm{t} 1 \mathrm{~b}$ (GACGAGATCGTTCATGTTGAACTC) (Oliveira et al. 2015a), and the ITS using ITS1 and ITS4. The resulting PCR products were submitted to 1st BASE (Malaysia) for forward and reverse sequencing reactions. Raw sequence data were assembled, examined, and manually edited using Genestudio 2.1.1.5 (Genestudio, Suwanee, Georgia) and BioEdit software (van der Nest et al. 2019). The DNA sequences were compared to the GenBank database via the nucleotide-nucleotide BLAST search interface located at the National Center for Biotechnology Information, Bethesda, USA. Relevant sequences were transferred with NoteTab Light v7.2.

\section{Phylogenetic analyses}

The sequences of Ceratocystis spp. closely related to the one from Mimusops elengi were retrieved from GenBank. Phylogenetic sequences from different gene regions were aligned using Mesquite v3.5 (Maddison and Maddison 2018) (http://mesquiteproject.org) and corrected manually. Phylogenetic trees based on a concatenated data set of the ITS and $\beta \mathrm{t}$ were computed and analyzed as a single dataset. Maximum Parsimony (MP) analyses were performed in MEGA v. 10 (Kumar et al. 2016; Paul et al. 2018) with 1000 bootstrap replications.

\section{Pathogenicity tests}

Pathogenicity studies were conducted on two agroforestry plants, $A$. mangium and $M$. elengi. Plants had stem diameters of $2-3 \mathrm{~cm}$ and heights $<1 \mathrm{~m}$. The pathogenic potential of isolates was evaluated by the under bark inoculation method described by Deidda et al. (2016). Bark was wounded to expose the cambium using a $4 \mathrm{~mm}$ cork borer, and discs of agar bearing mycelium taken from the margins of actively growing, 2-week-old cultures on 2\% MEA (Tarigan et al. 2010; Tarigan et al. 2011; Chi et al. 2019a, Chi et al. 2020), Ceratocystis isolates were placed with the mycelium facing the cambium. Ten plants of each tree species were inoculated with sterile MEA plugs to serve as controls. All inoculation points and the ends of the logs were covered with masking tape and polyethylene films, respectively, to prevent desiccation of the inoculum and cambium, and to reduce contamination.

The nursery trial evaluated seven Ceratocystis strains isolated from $M$. elengi (CAME30813, CAME30814, CAME30815, CAME30816, CAME30817, CAME30818 and CAME30819) and one strain (CAW30814) from $A$. mangium. There were ten replicate plants per treatment in each row plot in each of the blocks. After 45 days, lesion (L) length and foliar symptoms severity were recorded. Representative wood samples were taken from within 
lesions outside the inoculation area, and the pathogen reisolated and sequenced for Koch's postulates test.

Foliar symptoms severity (FS) was assessed using a scale of 0 to 4 : $0=$ healthy; $1=$ lower leaves yellow; $2=$ slight wilting; $3=$ severe wilting; $4=$ dead (Muslim et al. 2003; Chi et al. 2019a; Muslim et al. 2019).

The pathogenicity test data were analyzed using SAS university edition software package. Analysis of variance (ANOVA) and Tukey's honestly significant difference (Tukey's HSD) test were used to determine whether there were significant differences in comparisons of means of different treatments.

\section{RESULT AND DISCUSSION}

\section{Symptoms of Mimusops elengi wilt disease}

We observed disease symptoms from September 2019 to April 2020, in various places that are widely planted in the Indralaya (Ogan Ilir), Jakabaring (Palembang) and Kayuagung (Ogan Komering Ilir) areas, South Sumatra, Indonesia. The disease was found scattered throughout the planted area, with symptoms of partially dead trees, foliar wilting or loss and tree death (Figure 1a). Initially, the leaves of infected plants lost turgor and brightness, with yellowing symptoms in the older leaves, followed by wilting and death of the plant. Symptomatic plant stems showed xylem discoloration (Figure 1b), infections generally started in the roots and then moved upwards in the stem ultimately reaching the upper branches of the entire plant, and the plants ultimately died (Figure 1c).
Death of adjacent plants indicates transmission of root infection because these pathogens are also known as soilborne pathogens. The severity of the infection is also caused by pruning the branches using tools previously used to cut the infected plants.

Observation of diseased plant xylem tissue in crosssections of the stem showed dark brown lesion formation in the cambium (inner bark region) towards vascular tissue (Figure 1d). In the initial stage of plant infection, the foliar symptoms, wilt and the fruits appeared normal, but as the infection progressed, the fruits of affected plants were smaller, shriveled, wrinkled and dry. Many of the bark beetle vectors of $C$. manginecans, Hypocryphalus mangiferae were found around bullet wood diseases (Figure 1e). Testing by the Li et al. (2014) method showed that Ceratocystis had grown on the carrots, and ascomata of C. manginecans with necks supporting sticky masses of ascospores on the carrot slices (Figure 1.F).

\section{Sampling and isolation}

Seven isolates of $C$. manginecans were collected from diseased bullet wood ( $M$. elengi) (Figure 2). There were three isolates (CAME30815, CAME30816 and CAME30817) from Ogan Ilir (Indralaya); two isolates (CAME30818 and CAME30814) from Jakabaring (Palembang); and two isolates (CAME30819 and CAME30813) from Kayuagung (Ogan Komering Ilir). We also isolated one isolate (CAW30814) from diseased acacia, A. mangium in the agricultural field of Sriwijaya University, Indralaya.
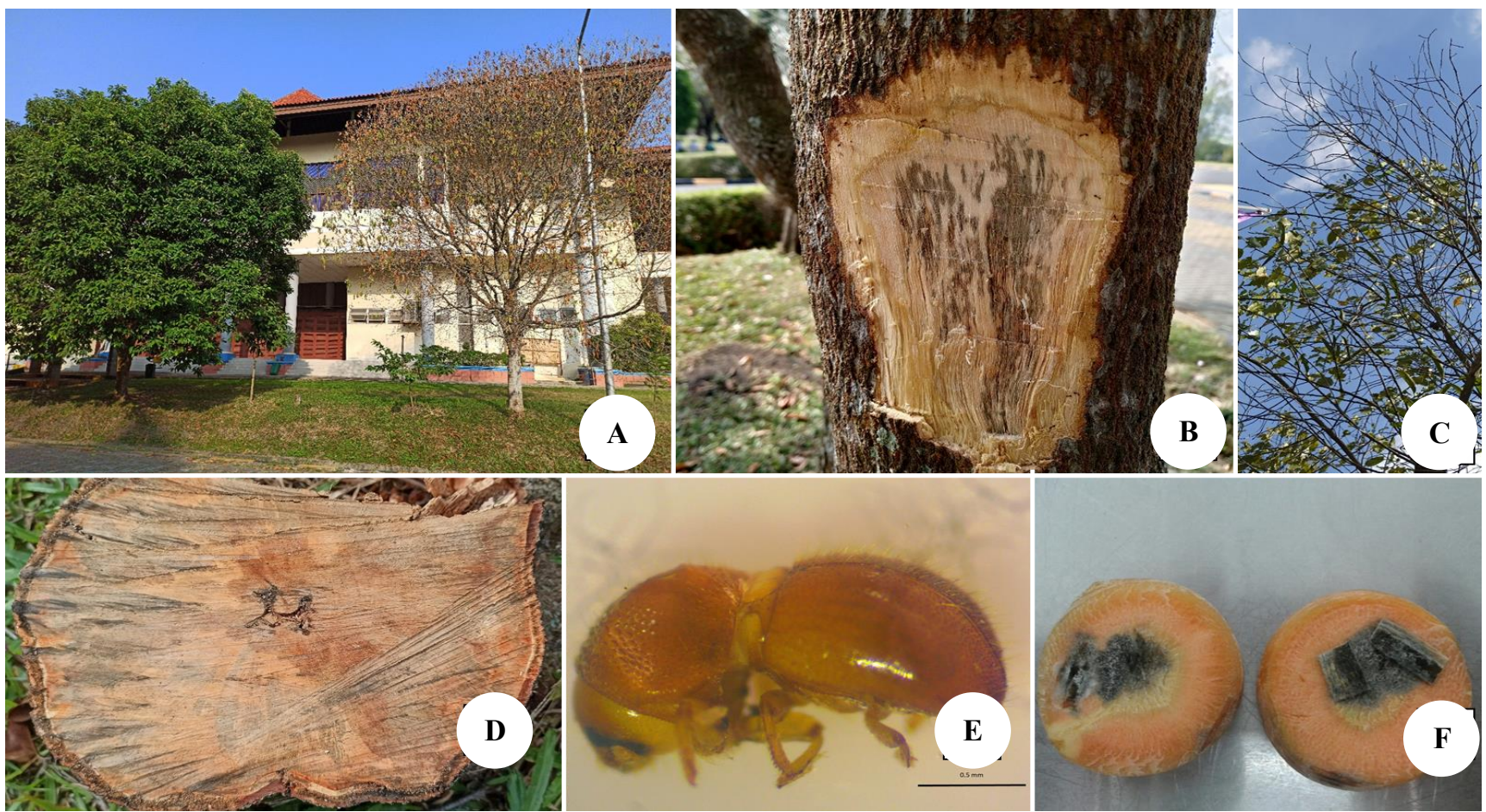

Figure 1. Symptoms of Ceratocystis manginecans wilt disease in bullet wood: a. tree death of M. elengi: b. sap stain mold on bullet wood, c. wilted leaves of bullet wood, d. sap stain mold on bullet wood, e. The bark beetle vector of C. manginecans, Hypocryphalus mangiferae, f. isolation of the fungus from discolored xylem showing dark mycelium and sporulation on the carrot slices 


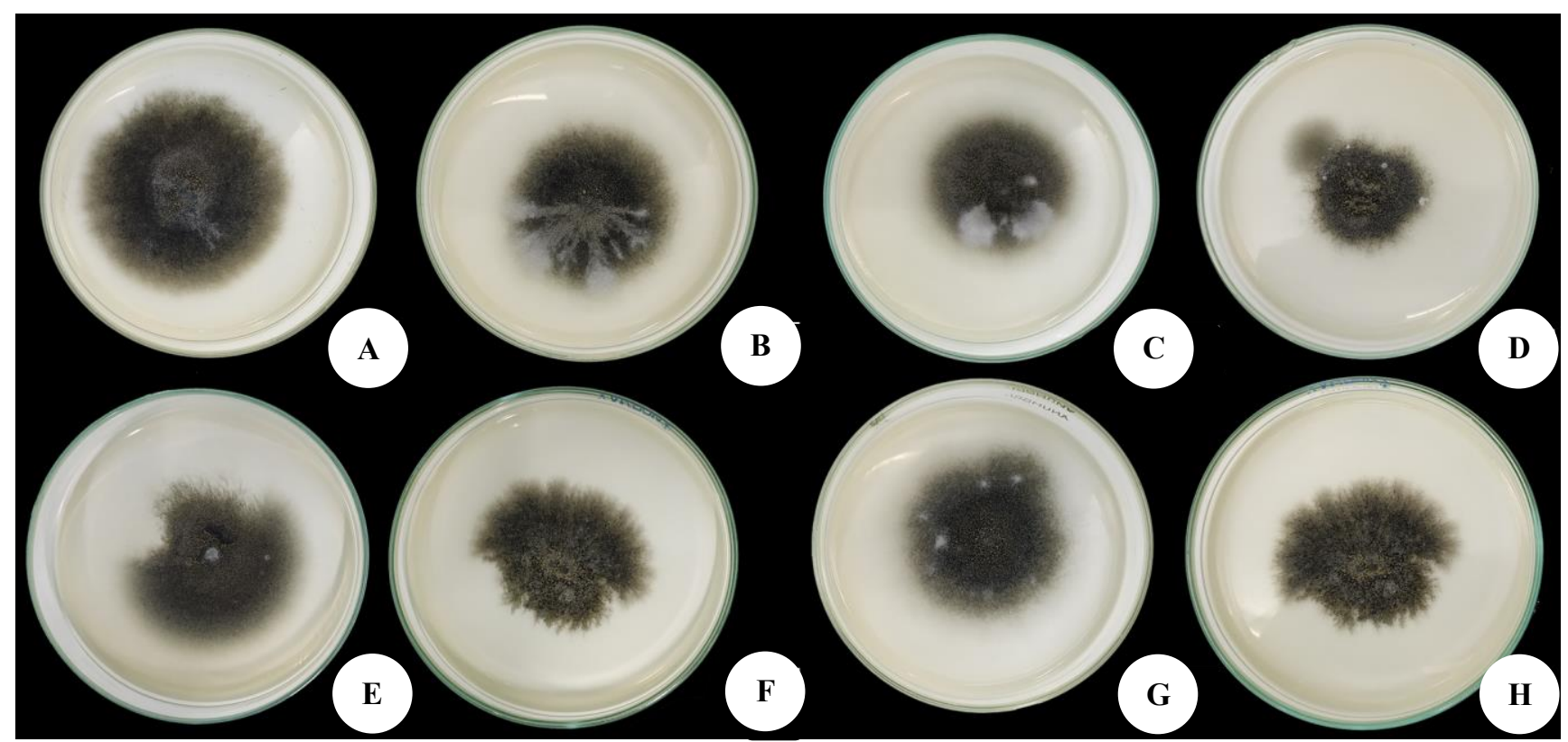

Figure 2. Isolates of Ceratocystis manginecans and related species grew on malt extract agar (MEA) for $7 \mathrm{~d}$ at $25{ }^{\circ} \mathrm{C} . \mathrm{A}, \mathrm{B}, \mathrm{C}$ : Ceratocystis CAME30815, CAME30816 and CAME30817, from Mimusops elengi in Sriwijaya University, Indralaya. D, E, F: Ceratocystis CAME30819, CAME30813 and CAME30814 from Mimusops elengi in Jakabaring, Palembang. G: Ceratocystis CAME30818, from Mimusops elengi in Kayuagung, Ogan Komering Ilir. H: Ceratocystis CAW30814, from Acacia mangium in Indralaya

\section{Fungal morphology}

Seven isolates were morphologically indistinguishable (Table 2). At $7-14$ days of incubation at $25{ }^{\circ} \mathrm{C}$ on MEA, cultures were pale brown to dark brown and produced a banana-like odor. Mycelium on MEA was grey, and the reverse side of the colony olivaceous grey; submerged mycelium darkened as the ascomata developed, forming fine, radiating fibrils. Ascomata developing within seven days and mature within ten days, superficially or partly embedded in the agar, dark brown to black (Figure 3a). Ascomatal bases were submerged or on the agar surface, dark bases dark brown to black, base subglobose to globes, (134.58-) 169.12 - 276.29 (-310.83) $\mu \mathrm{m}$ long and (122.91-) $161.89-244.14(-283.13) \mu \mathrm{m}$ wide in diameter (Figure 3a). Ascomata necks were erect, occasionally curved, black at the base becoming subhyaline towards the apex, smooth to crenulate, (346.51-) 454.94-720.16 (-828.59) $\mu \mathrm{m}$ long including ostiolar hyphae (Figure3b). Ascospores were hatshaped, (3.61-) 5.64-6.23 (-6.93) $\mu \mathrm{m}$ length and (2.06-) 2.279-3.67 (-3.85) $\mu \mathrm{m}$ width (Figure 3f). Barrel conidia (8.62-) 8.85-12.79 (-13.25) $\mu \mathrm{m}$ length and (5.89-) $4.12 \times 6.87(-8.67) \mu \mathrm{m}$ width. Bacilliform conidia (9.05-) 10.82-22.32 (-35.97) $\mu \mathrm{m}$ length and (2.01-) 2.83-5.71 (8.87) $\mu \mathrm{m}$ width (Figure 3c). Chlamydospores oval, thickwalled, smooth, (8.21-) 9.15-16.21 (-18.50) $\mu \mathrm{m}$ length and (4.92-) 6.46-15.81 (14.65) $\mu \mathrm{m}$ width (Figure 3e).

\section{Sequence analysis}

To confirm the identity of the wilt pathogen, the ITS and $\beta$-tubulin 1 gene sequences of two isolates from bullet wood (M. elengi) were compared to reference sequences downloaded from the gene bank database (NCBI GenBank) (Table 1) and indicated that isolates from Indonesia were grouped within the C. fimbriata. s.l species complex and were most closely related to $C$. manginecans. PCR amplification resulted in fragments of $\sim 550$ base pairs (bp) in size which had $100 \%$ homology with $C$. manginecans (Figure 4). Bootstrap values were equal to or greater than $50 \%$, derived from 1000 iterations.

\section{Pathogenicity}

The results of the pathogenicity tests of seven isolates (CAME30813, CAME30814, CAME30815, CAME30816, CAME30817, CAME30818, and CAME30819) on $M$. elengi and one isolate (CAW30814) from A. mangium are shown in Table 3. All isolates tested showed a varying reaction to lesion and foliar symptoms (Figure 5). For the pathogenicity test on $M$. elengi, seven isolates from $M$. elengi as well as one isolate from A. mangium strongly infected the wood and produced significant lesion lengths ranging from 3.99 to $10.47 \mathrm{~cm}$ and showed significant differences from the control. Three isolates from M. elengi (CAME30815; CAME30819; CAME30818) as well as one isolate from $A$. mangium (CAW30814) showed high pathogenicity on the foliar symptom (with foliar severity index of 2.3-3.6 and lesion length $6.52-10.47 \mathrm{~cm}$ ), while the other isolates (CAME30817; CAME30816; CAME30814, CAME30813) showed moderate pathogenicity to $M$. elengi (foliar severity index of 1.4-2.0 and lesion length 3.99-6.02 cm). When the isolates were tested for their pathogenicity on A. mangium as the primary host of the pathogen, two isolates (CAME30815; CAME30819) showed strong pathogenicity on lesion length (13.76-11.89 cm) and also provided high pathogenicity on foliar severity index (4), where all plants tested were dead. Three isolates (CAW30814; 
CAME30818; CAME30817) showed moderate pathogenicity on lesion length $8.71-10.14 \mathrm{~cm}$ and foliar severity index 2.8-3.2, while the other isolates
(CAME30816, CAME30814, CAME30813) showed low pathogenicity on lesion length $7.19-8.63 \mathrm{~cm}$ and foliar severity index 1.9-2.4.

Table 1. Ceratocystis isolates considered in the phylogenetic analyses

\begin{tabular}{|c|c|c|c|c|c|c|}
\hline \multirow[t]{2}{*}{ Isolate no } & \multirow[t]{2}{*}{ Identify } & \multirow[t]{2}{*}{ Host } & \multirow{2}{*}{$\begin{array}{c}\text { Geographic } \\
\text { origin }\end{array}$} & \multirow[t]{2}{*}{ Collector } & \multicolumn{2}{|c|}{$\begin{array}{c}\text { Gene region/GeneBank } \\
\text { accession no }\end{array}$} \\
\hline & & & & & ITS & BT \\
\hline CAME30819 & C.manginecans & Mimusops elengi & Indonesia & R.Pratama & MT373423 & Submitted \\
\hline CAME30818 & C.manginecans & Mimusops elengi & Indonesia & R.Pratama & MT373424 & Submitted \\
\hline CMW13851 & C.manginecans & Mangifera indica & Oman & M. Deadman & AY953383 & EF433308 \\
\hline CMW23643 & C.manginecans & Mangifera indica & Pakistan & A.Al-Adawi & EF433304 & EF433313 \\
\hline CMW23641 & C.manginecans & Mangifera indica & Pakistan & A.Al-Adawi & EF433305 & EF433314 \\
\hline CMW23634 & C.manginecans & Mangifera indica & Pakistan & A. Al-Adawi & EF433302 & EF433311 \\
\hline CMW21125 & C.manginecans & A. crassicarpa & Indonesia & M. Tarigan & EU588663 & EU588642 \\
\hline CMW21123 & C.manginecans & A. crassicarpa & Indonesia & M. Tarigan & EU588662 & EU588641 \\
\hline CMW22581 & C.manginecans & Acacia mangium & Indonesia & M. Tarigan & EU588659 & EU604671 \\
\hline CMW21132 & C.manginecans & A. crassicarpa & Indonesia & M. Tarigan & EU588665 & EU588644 \\
\hline CMW22579 & C.manginecans & Acacia mangium & Indonesia & M. Tarigan & EU588658 & EU588638 \\
\hline CMW23628 & C.manginecans & Hypocryphalus mangifera & Pakistan & A. Al-Adawi & EF433303 & EF433312 \\
\hline CMW13854 & C.manginecans & Mangifera indica & Oman & M. Deadman & AY953385 & EF433310 \\
\hline CMW13852 & C.manginecans & Hypocryphalus mangifera & Oman & M. Deadman & AY953384 & EF433309 \\
\hline CMW4068 & C.albifundus & A. mearnsii & RSA & J. Roux & DQ520638 & EF070429 \\
\hline CMW14793 & C.caryae & C. cordiformis & U.S.A & J. Johnson & EF070424 & EF070439 \\
\hline CMW14800 & C.smalleyi & C. cordiformis & U.S.A & G. Smalley & EF070420 & EF070436 \\
\hline \multicolumn{7}{|l|}{ CBS114724 } \\
\hline CMW14789 & C. populicola & Populus sp. & Poland & J. Gremmen & EF070418 & EF070434 \\
\hline CMW19385 & C.atrox & E. grandis & Australia & M.J. Wingfield & EF070415 & EF070431 \\
\hline \multicolumn{7}{|l|}{ CBS115778 } \\
\hline CMW11424 & C. polycroma & Syzygium aromaticum & Indonesia & M.J. Wingfield & AY528970 & AY528966 \\
\hline CMW23808 & C. obpyriformis & A. mearnsii & South Africa & R.N. Heath & EU245003 & EU244975 \\
\hline CMW6579 & C.pirilliformis & E. nitens & Australia & M.J. Wingfield & AF427105 & DQ371653 \\
\hline
\end{tabular}

Table 2. Morphological comparisons of Ceratocystis manginecans and other phylogenetically closely related species

\begin{tabular}{|c|c|c|c|}
\hline Character & $\begin{array}{c}\text { Ceratocystis manginecans } \\
\text { (from } M . \text { elengi) }\end{array}$ & $\begin{array}{c}\text { Ceratocystis acaciivora } \\
\text { (from } A \text {. mangium) }\end{array}$ & $\begin{array}{l}\text { Ceratocystis manginecans } \\
\text { (from } \text { A. mangium) }\end{array}$ \\
\hline Ascomata base & $\begin{array}{l}(134.58-) 169.12-276.29(-310.83) \mathrm{x} \\
(122.91-) 161.89-244.14(-283.13)^{\mathrm{a}}\end{array}$ & $\begin{array}{l}(105-) 131-175(-206) \times(107- \\
125-167(-188)\end{array}$ & $(132.1-) 175.3(-233.2)$ \\
\hline Ascomata base average & $220.01 \times 211.63^{\mathrm{b}}$ & & \\
\hline Ascomata neck & (346.51-) 454.94-720.16 (-828.59) & (301-) 348-448 (-522) & $(327.3-) 452.7(-556)$ \\
\hline Ascomata neck average & 568.41 & & \\
\hline Ascospores & $\begin{array}{l}(3.61-) 5.64-6.23(-6.93) \times(2.06-) 2.279-3.67 \\
(-3.85)\end{array}$ & $5-7 \times 3-4$ & $\begin{array}{l}(3.1-) 4.2(-4.7) \times(4.1-) \\
5.5(-6.8)\end{array}$ \\
\hline Ascospores average & $5.62 \times 3.93$ & & \\
\hline Bacilliform conidia & $\begin{array}{l}(9.05-) 10.82-22.32(-35.97) \times(2.01-) 2.83- \\
5.71(-8.87)\end{array}$ & $(11-) 14-22(-29) \times 3-5$ & $\begin{array}{l}(14.6-) 18.6(-30.7) \times(3.0- \\
) 4.6(-5.4)\end{array}$ \\
\hline Bacilliform conidia average & $16.56 \times 4.27$ & & \\
\hline Barrel-shaped conidia & $\begin{array}{l}(8.62-) 8.85-12.79(-13.25) \times(5.89-) \\
4.12 \times 6.87(-8.67)\end{array}$ & $(8-) 9-11(-13) \times 4-6$ & (6.8) $8.1(-10.6)$ \\
\hline $\begin{array}{l}\text { Barrel-shaped conidia } \\
\text { average }\end{array}$ & $11.497 \times 15.82$ & & \\
\hline Clamydospore & $\begin{array}{l}(8.21-) 9.15-16.21(-18.50) \times(4.92-) 6.46- \\
15.81(14.65)\end{array}$ & $\begin{array}{l}(10-) 12-14(-15) \times(7-) 8-12 \\
(-14)\end{array}$ & $\begin{array}{l}(10.1-) 13.1(-15.5) \mathrm{x} \\
(6.1-) 9.2(-11.1)\end{array}$ \\
\hline Clamydospore average & $11.13 \times 14.18$ & & \\
\hline Reference & This study & M. Tarigan et al. (2010) & Chi et al. (2019) \\
\hline
\end{tabular}


Table 3. Pathogenicity of Ceratocystis isolates on Mimusops elengi and Acacia mangium under nursery condition

\begin{tabular}{lccccc}
\hline \multirow{2}{*}{ Isolates } & \multirow{2}{*}{ Host test } & \multicolumn{2}{c}{ M. elengi } & \multicolumn{2}{c}{ A. mangium } \\
\cline { 3 - 6 } & & Lesion length (cm) & Foliar symptoms & Lesion Length (cm) & Foliar symptoms \\
\hline CAME30815 & 10 & $10.47 \mathrm{e}$ & 3.6 & $13.77 \mathrm{~d}$ & 4 \\
CAME30819 & 10 & $8.29 \mathrm{de}$ & 3.1 & $11.89 \mathrm{~cd}$ & $10.14 \mathrm{bcd}$ \\
CAW30814 & 10 & $7.35 \mathrm{~cd}$ & 2.8 & $9.92 \mathrm{bcd}$ & 3.2 \\
CAME30818 & 10 & $6.52 \mathrm{bcd}$ & 2.3 & $8.72 \mathrm{bc}$ & 3.1 \\
CAME30817 & 10 & $6.02 \mathrm{bcd}$ & 2 & $8.47 \mathrm{bc}$ & 2.8 \\
CAME30816 & 10 & $5.27 \mathrm{bc}$ & 1.8 & $8.64 \mathrm{bc}$ & 2.4 \\
CAME30814 & 10 & $4.93 \mathrm{bc}$ & 1.5 & $7.19 \mathrm{~b}$ & 1.9 \\
CAME30813 & 10 & $3.99 \mathrm{~b}$ & 1.4 & $0.1 \mathrm{a}$ & 0 \\
Control (MEA) & 10 & $0.1 \mathrm{a}$ & 0 & $<0.001$ &
\end{tabular}

Note: Values followed by the same letters in a column are not different among isolates at $\mathrm{P}=0.05$ according to Tukey's HSD multiple range test.
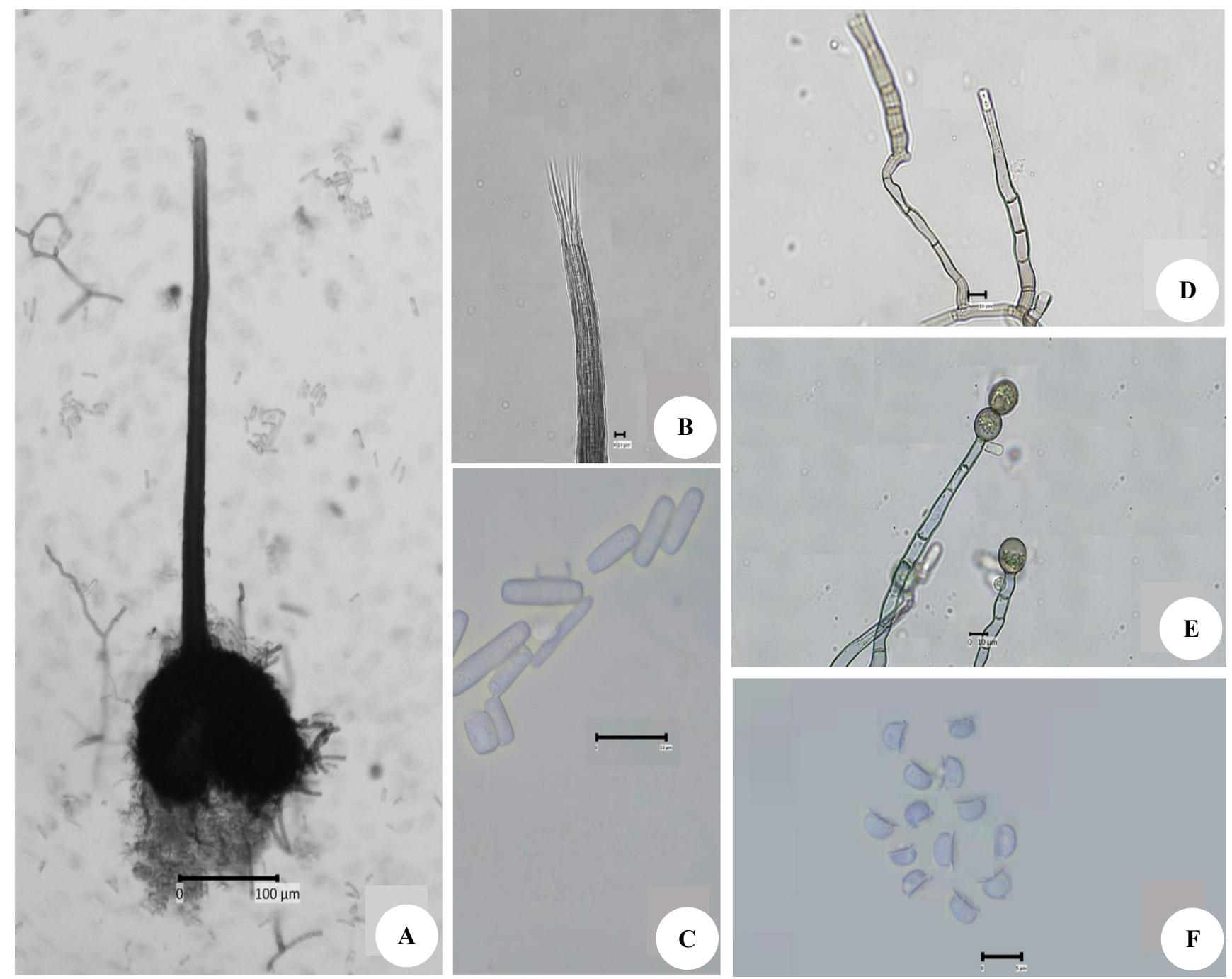

Figure 3. Morphological characteristics of Ceratocystis isolated from M. elengi stem lesion: A. Globose ascomata with long neck, B. Divergent ostiolar hyphae, C. Barrel-shaped conidia, D. Conidiophore/phialide, E. Chlamydospores, F. Hat-shaped ascospores. Scale bars: $\mathrm{A}=100 \mu \mathrm{m} ; \mathrm{B}, \mathrm{C}, \mathrm{D}, \mathrm{E}=10 \mu \mathrm{m} ; \mathrm{F}=5 \mu \mathrm{m}$ 


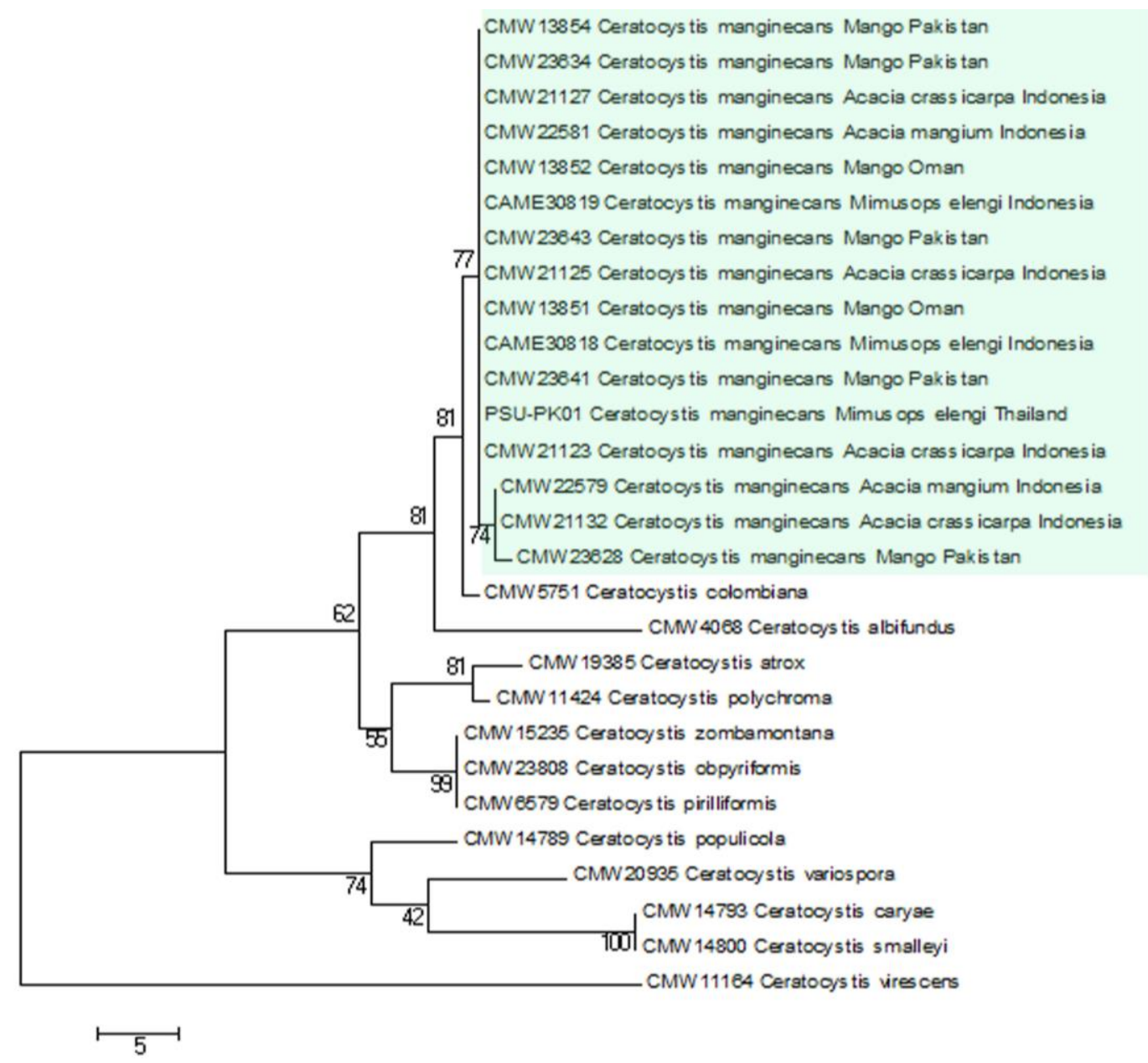

Figure 4. Phylogenetic tree constructed by MEGA with Maximum Parsimony (MP). The tree was built using combined sequence data of the ITS region and b-tubulin gene and their related species from GenBank. Consistency (CI), retention (RI), and composite indexes (CoI) are $0.714286,0.837209$, and 0.664843 for all sites and parsimony-informative sites. The percentage of replicate trees in which the associated taxa clustered together in the bootstrap test (1000 replicates) is shown next to the branches. Bootstrap values $>50 \%$ are indicated above the branches. The analysis involved 28 nucleotide sequences. All positions containing gaps and missing data were eliminated. There were 493 positions in the final dataset
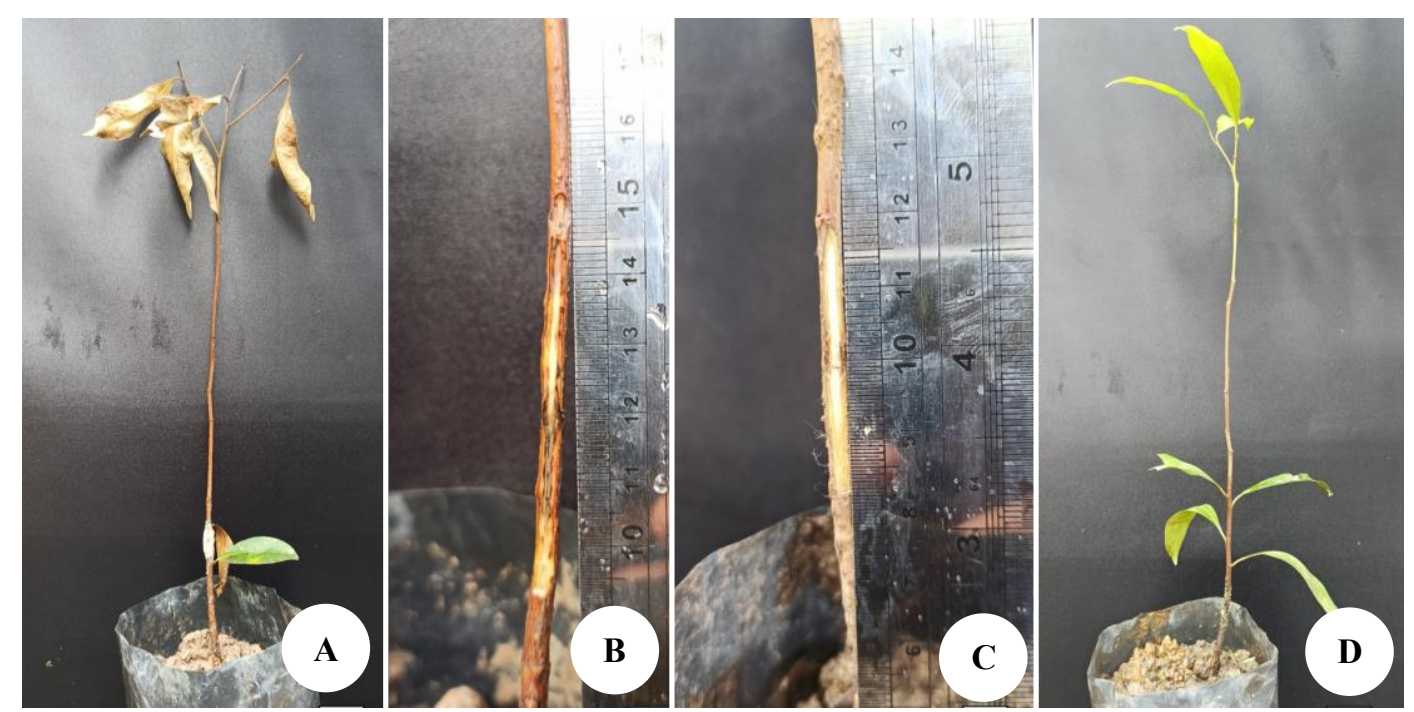

Figure 5. Response after 45 days of Mimusops elengi seedlings to under-bark inoculation with mycelium of Ceratocystis manginecans. A. Wilting of seedlings; B. Lesions on the stem; C. No lesions on the stem; D. Normal foliage on the control seedling which received MEA only and appeared healthy. Yellow arrow indicates the point of inoculation, red arrows show the lesion boundary 


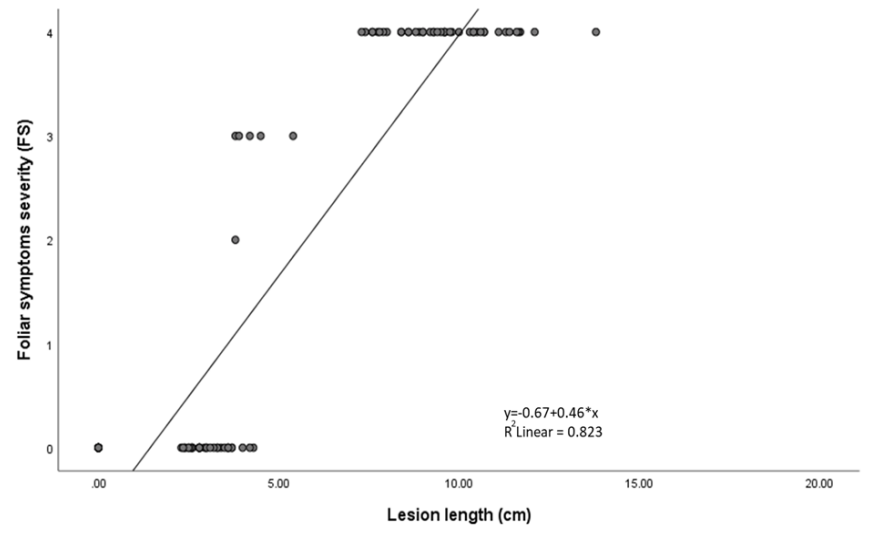

$\mathbf{A}$

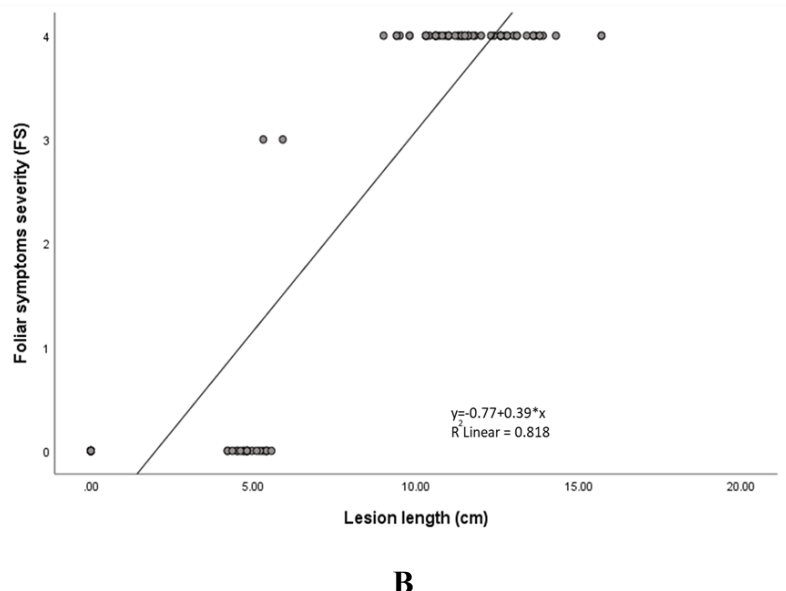

B

Figure 6. Correlation between foliar symptoms severity (FS) and lesion length (cm): A. Mimusops elengi, B. Acacia mangium

There was a strong linear correlation between foliar symptom severity and lesion length for $M$. elengi and $A$. mangium (Figure 6). The Koch's postulates test was conducted by reisolating the pathogen, and its identity confirmed to be the same as $C$. manginecans.

\section{Discussion}

The results of this study show clearly that $C$. manginecans was responsible for the wilt outbreak disease that has recently appeared on the $M$. elengi agricultural field in Indralaya (Ogan Ilir) and roadside trees in Jakabaring (Palembang) and Kayuagung (Ogan Komering Ilir), South Sumatra. This is the first report of a Ceratocystis wilt disease on $M$. elengi in Indonesia. Formerly the disease was reported in Thailand (Pornsuriya and Sunpapao 2015), however, they just observed a single tree and they did not conduct pathogenicity tests and observe morphological characteristics. In Indonesia Tarigan et al. $(2010 ; 2011)$ reported $C$. manginecans caused wilt and die-back disease in $A$. mangium plantations in Riau and Suwandi et al. (2021) have reported infection of this disease on Lansium domesticum tree.

Mimusops elengi infected with Ceratocystis has wilted foliage symptoms, sudden wilt, decline and branch drying, and progressive loss of the canopy resulting in tree death. $M$. elengi trees showed typical symptoms of infection by the Ceratocystis fungus; the same was true of a serious wilt pathogen of $A$. mangium and $A$. crassicarpa in Indonesia and Vietnam (Tarigan et al. 2011; Thu et al. 2012; Thu et al. 2016). Vascular wilt, wood stain and stem cankers are the most characteristic symptoms of infection by $C$. manginecans in woody trees (Harrington 2013). Rot in roots or stems, vascular wilt, sapwood discoloration and cankers are symptomatic of plants infected by $C$. manginecans species (Oliveira et al. 2015b).

The comparison of morphological characteristics and gene sequences ( $\beta$-tubulin and ITS) of the isolates examined in this study were similar to those in descriptions given for $C$. manginecans isolated from diseased Acacia trees which form part of the $C$. fimbriata s. 1. complex, which is typified by $C$. fimbriata sensu stricto (Engelbrecht and Harrington 2005; Tarigan et al. 2011). The two isolates from Indralaya (Ogan Ilir), Jakabaring (Palembang) and Kayuagung (Ogan Komering Ilir) have 100\% identical sequences of ITS and Beta Tubulin representing a single clone of the pathogen. This supports the view that $M$. elengi wilt disease in Indralaya (Ogan Ilir), Jakabaring (Palembang) and Kayuagung (Ogan Komering Ilir) emerged from a single introduction of a single haplotype and the population has expanded clonally to infect $M$. elengi trees in many parts of all three regions.

Ceratocystis manginecans was reported in Indonesia associated with wilt and die-back disease on Acacia spp. (Tarigan et al. 2011). It was found that many acacia plants were attacked by Ceratocystis disease and Hypocryphalus mangifera insects in the field raised the suspicion that $M$. elengi were infected by Ceratocystis in acacia plants. $H$. mangifera is a vector insect for the spread of Ceratocystis in the world (Van Wyk et al. 2007; Masood et al. 2008; AlAdawi et al. 2013; Fourie et al. 2016). Pruning M. elengi branches using equipment that has previously been infected with Ceratocystis also increases the severity of the disease; this can be seen by the number of plants that are attacked after pruning with tools used to prune Acacia plants that are attacked by Ceratocystis. Cankers of Ceratocystis were associated with branch wounds from pruning, pruning time and pruning technique on plants (Chi et al. 2019b). In this study, infected bullet wood was observed surrounding infected acacia by $C$. manginecans with abundant $H$. mangifera. This might be caused by spore contamination on cutting tools after pruning diseased acacia and spore spreading by insect vector $H$. mangifera.

The pathogenicity of $C$. manginecans to these hosts was demonstrated in inoculation trials and it is clear that the fungus is responsible for the widespread death of these trees. It was also possible to show that isolates of the pathogen from these trees are able to infect and kill other plants. The eight $C$. manginecans isolates all formed lesions on the stems of $M$. elengi seedlings when inoculated under the bark in nursery cloches. The most pathogenic was CAME30815 and CAME30819 isolate from $M$. elengi and the CAW30814 isolate from $A$. mangium resulted in 
foliar symptoms with severity index 3.6, 3.1, and 2.8 after 45 days from inoculation with pathogen. When the isolates were tested on seedling A. mangium, the seedlings were infected and mostly dead as they were the main host plant and susceptible to $C$. manginecans (Tarigan et al. 2011).

Previous researchers of $C$. manginecans on M. elengi in Thailand have reported molecular identification $C$. manginecans by primers combination the ITS, $\beta$-tubulin $(\beta \mathrm{t})$ and transcribed elongation factor 1- $\alpha$ (TEF1- $\alpha$ ) gene regions with one isolate. In our research, we tested two isolates for sequencing, seven isolates for pathogenicity, and Koch's postulates assay using three isolates (CAME30815, CAME30816 and CAME30817) from Ogan Ilir (Indralaya); two isolates (CAME30818 and CAME30814) from Jakabaring (Palembang); and two isolates (CAME30819 and CAME30813) from Kayuagung (Ogan Komering Ilir) and one isolate (CAW30814) from diseased Acacia, A. mangium. All isolates showed the ability to infect both bullet wood and Acacia, and all isolates can be reisolated confirming Koch's postulates.

The wilt disease of M. elengi appears to be serious and it is clearly a new host tree or pathogen association that has apparently occurred due to a host shift. This category of diseases is increasing in importance in plants, and they can devastate native trees that have not previously encountered them (Roy 2001; Anderson et al. 2004; Slippers et al. 2005; Woolhouse et al. 2005; Desprez-Loustau et al. 2007; Wingfield et al. 2010). In this regard, the wilt disease of $M$. elengi can impact seriously on the natural biodiversity of Indonesia, and studies should be instituted to understand them better. The findings of this study will give knowledge of the characteristics of the symptoms of the disease, their causes and help to minimize the spread of wilt disease in M. elengi in plantations or roadside trees and to consider its possible pathogenicity.

This study presents the first report of Ceratocystis wilt or sudden decline disease of bullet wood in Indonesia and the discovery of a fungus that has been identified as $C$. manginecans. The disease of bullet wood that gave rise to this study is serious and management options to reduce its incidence are required C. manginecans is an aggressive pathogen and a deeper understanding of its role in tree death will be important in the future.

\section{ACKNOWLEDGEMENTS}

This research was funded by a PMDSU scholarship in the fiscal year of 2019-2021 according to the Director of Research and Community Service, Directorate of Research and Community Service (DRPM), Directorate General for Research and Development, Ministry of Research, Technology, and Higher Education Indonesia, Number: 068/SP2H/AMD/LT/DRPM/2020 chaired by Ahmad Muslim.

\section{REFERENCES}

Al Adawi AO, Barnes I, Khan IA, Al Subhi AM, Al Jahwari AA, Deadman ML, Wingfield BD, Wingfield MJ. 2013. Ceratocystis manginecans associated with a serious wilt disease of two native legume trees in Oman and Pakistan. Australas Plant Pathol 42:179193. DOI: 10.1007/s13313-012-0196-5.

Ali MA, Mozid MA, Yeasmin MS, Khan AM, Sayeed MA. 2008. An evaluation of antimicrobial activities of Mimusops elengi Linn. Res J Agric Biol Sci 4: 871-874.

Anderson PK, Cunningham AA, Patel NG, Morales FJ, Epstein PR, Daszak P. 2004. Emerging infectious diseases of plants: Pathogen pollution, climate change and agrotechnology drivers. Trends Ecol Evol 19:535-544. DOI: 10.1016/j.tree.2004.07.021.

Chi NM, Nhung NP, Trang TT, Thu PQ, Hinh TX, Nam NV, Quang DN, Dell B. 2019a. First report of wilt disease in Dalbergia tonkinensis caused by Ceratocystis manginecans. Australas Plant Pathol 48: 439445. DOI: 10.1007/s13313-019-00643-1.

Chi NM, Thu PQ, Hinh TX, Dell B. 2019b. Management of Ceratocystis manginecans in plantations of Acacia through optimal pruning and site selection. Australas Plant Pathol 48: 343-350. DOI: 10.1007/s13313-019-00635-1.

Chi NM, Trang TT, Nhung NP, Quang DN, Son VM, Tuan TA, Mai LT, Hung TX, Nam NV, Thu PQ, Dell B. 2020. Ceratocystis wilt in Chukrasia tabularis in Vietnam: Identification, pathogenicity and host tolerance. Australas Plant Pathol 50: 17-27. DOI: 10.1007/s13313-020-00754-0.

Deidda A, Buffa F, Linaldeddu BT, Pinna C, Scanu B, Deiana V, Satta A, Franceschini A, Floris I. 2016. Emerging pests and diseases threaten Eucalyptus camaldulensis plantations in Sardinia, Italy. Iforest 9: 883-891. DOI: 10.3832/ifor1805-009.

Desprez-Loustau ML, Robin C, Buee M, Courtecuisse R, Garbaye J, Suffert F, Sache I, Rizzo DM. 2007. The fungal dimension of biological invasions. Trends Ecol Evol 22: 472-480. DOI: 10.1016/j.tree.2007.04.005.

Engelbrecht CJB, Harrington TC. 2005. Intersterility, morphology and taxonomy of Ceratocystis fimbriata on sweet potato, cacao and sycamore. Mycologia 97:57-69. DOI: 10.3852/mycologia.97.1.57.

Fourie A, Wingfield MJ, Wingfield BD, Thu PQ, Barnes I. 2016. A possible centre of diversity in South East Asia for the tree pathogen, Ceratocystis manginecans. Infect Genet Evol 41: 73-83. DOI: 10.1016/j.meegid.2016.03.011.

Harrington TC. 2013. Ceratocystis diseases. In: Gonthier P (eds). Infectious Forest Diseases. CABI, Wallingford.

Khatun S, Cakilcioglu U, Chakrabarti M, Ojha S, Chatterjee NC. 2011. Biochemical defense against die-back disease of a traditional medicinal plant Mimusops elengi Linn. European J Med Plants 1: 4049. DOI: 10.9734/EJMP/2011/247.

Kumar H, Savaliya M, Biswas S, Nayak PG, Maliyakkal N, Setty MM, Gourishetti K, Pai KSR. 2016. Assessment of the in vitro cytotoxicity and in vivo anti-tumor activity of the alcoholic stem bark extract/fractions of Mimusops elengi Linn. Cytotechnology 68: 861877. DOI: 10.1007/s10616-014-9839-4.

Li J, Gao J, Han YH, Sun YX, Huang Q. 2014. First report of Ceratocystis fimbriata-caused wilt of Eriobotrya Japonica in China. Plant Dis 98: 1270. DOI: 10.1094/PDIS-12-13-1290-PDN.

Lim TK. 2012. Mimusops elengi. Edible Medicinal and Non-Medicinal Plants. Springer Science+Business Media, New York. DOI: 10.1007/978-94-007-1764-0.

Lokesh S, Raghavendra VB, Sugnanachar N, Melappa G. 2017. First Report of leaf blight of bakul (Mimusops elengi Linn) caused by Pestalotiopsis clavispora (G.F. Atk.) Steyaert in India. J Plant Physiol Pathol 5: 1-3.

Maddison WP, Maddison DR. 2018. Mesquite: A Modular System for Evolutionary Analysis. Available via: http://mesquiteproject.org

Masood A, Saeed S, Sajjad A. 2008. Characterization and damage patterns of different bark beetle species associated with mango sudden death syndrome in Punjab, Pakistan. Pak Entomol 30: 163-168.

Muslim A, Horinouchi H, Hyakumachi M. 2003. Biological control of Fusarium wilt of tomato with Hypovirulent Binucleate Rhizoctonia in greenhouse conditions. Mycoscience 44:77-84. DOI: 10.1007/S10267-002-0084-x.

Muslim A, Hyakumachi M, Kageyama K, Suwandi S, Pratama R. 2019. A rapid bioassay to evaluate efficacy of Hypovirulent Binucleate Rhizoctonia in reducing Fusarium Crown and root rot of tomato. The Open Agric J 13: 27-33. DOI: 10.2174/1874331501913010027.

Oliveira SS, Harrington TC, Ferreira MA, Damacena MB, Al-Sadi AM, Al-mahmooli HIS, Alfenas AC. 2015a. Species or genotypes? Reassessment of four recently described species of the Ceratocystis 
wilt pathogen, Ceratocystis fimbriata, on Mangifera indica. Mycology 105: 1229-1244. DOI: 10.1094/PHYTO-03-15-0065-R

Oliveira LSS, Harrington TC, Freitas RG, McNew D, Alfenas AC. 2015b. Ceratocystis tiliae sp. nov., a wound pathogen on Tilia Americana. Mycologia 107: 986-995. DOI: 10.3852/14-273.

Paul CN, Nam SS, Kachroo A, Kim HY, Yang JW. 2018. Characterization and pathogenicity of sweet potato (Ipomoea batatas) black rot caused by Ceratocystis fimbriata in Korea. Eur J Plant Pathol: 7-8. DOI: 10.1007/s10658-018-1522-8.

Pokale P, Shende S, Gade A, Rai M. 2014. Biofabrication of calcium phosphate nanoparticles using the plant Mimusops elengi. Environ Chem Lett 12: 393-399. DOI: 10.1007/s10311-014-0460-8.

Pornsuriya C, Sunpapao A. 2015. A new sudden decline disease of bullet wood in Thailand is associated with Ceratocystis manginecans. Aust Plant Dis Notes 10:26-31. DOI: 10.1007/s13314-015-0176-z.

Razzaq K, Anjum R, Hanif S, Sultan A. 2020. First report of Ceratocystis manginecans causing Siris (Albizia lebbeck) wilt in Pakistan. Plant Dis 104: 1-3. DOI: 10.1094/PDIS-10-19-2057-PDN.

Roy BA. 2001. Patterns of association between crucifers and their flowermimic pathogens: Host jumps are more common than co-evolution or co-speciation. Evolution 55:41-53. DOI: 10.1111/j.00143820.2001.tb01271.x.

Seth MK. 2003. Trees and their economic importance. Bot Rev 69: 321376. DOI: 10.1663/0006-8101(2004)069[0321:TATEI]2.0.CO;2.

Slippers B, Stenlid, J, Wingfield, MJ. 2005. Emerging pathogens: Fungal host jumps following anthropogenic introduction. Trends Ecol Evol 20: 420-421. DOI: 10.1016/j.tree.2005.05.002.

Suwandi S, Irsan C, Hamidson H, Umayah A, Asriyani KD. 2021. Identification and Characterization of Ceratocystis fimbriata Causing Lethal Wilt on the Lansium Tree in Indonesia. Plant Pathol J 37:124136. DOI: 10.5423 /PPJ.OA.08.2020.0147
Tarigan M, Roux J, Wingfield MJ, VanWyk M, Tjahjono B. 2010. Three new Ceratocystis spp. in the Ceratocystis moniliformis complex from wounds on Acacia mangium and A. crassicarpa. Mycoscience 51: 5367. DOI: $10.1007 /$ S10267-009-0003-5.

Tarigan M, Roux J, Van Wyk M, Tjahjono B, Wingfield MJ. 2011. A new wilt and die-back disease of Acacia mangium associated with Ceratocystis manginecans and C. acaciivora $\mathrm{sp}$. nov. in Indonesia. S Afr J Bot 77: 292-304. DOI: 10.1016/j.sajb.2010.08.006.

Thu PQ, Quynh DN, Dell B. 2012. Ceratocytis sp. causes crown wilt of Acacia spp. planted in some ecological zones of Vietnam. J Plant Prot 5: 24-29.

Thu PQ, Chi NM, Tam TTT. 2016. Ceratocystis wilt disease of Acacia auriculiformis, Acacia mangium and Acacia hybrid in Vietnam. Sci Tech J Agric Rural Dev 8:134-140.

Van der Nest MA, Steenkamp ET, Roodt D, Soal NC, Palmer M, Chan WY, Wilken PM, Duong TA, Naidoo K, Santana QC, Trollip C, Vos LD, van Wyk S, McTaggart AR, Wingfield MJ, Wingfield BD. 2019. Genomic analysis of the aggressive tree pathogen Ceratocystis albifundus. Fungal Biol 123: 351-363. DOI: 10.1016/j.funbio.2019.02.002.

Van Wyk M, Al Adawi AO, Khan IA, Deadman ML, Al Jahwari AA, Wingfield BD, Ploetz R, Wingfield MJ. 2007. Ceratocystis manginecans sp. nov., causal agent of a destructive mango wilt disease in Oman and Pakistan. Fungal Divers 27: 213-230.

Wingfield MJ, Slippers B, Wingfield BD. 2010. Novel association between pathogens, insects and tree species threaten world forests. N Z J For Sci 40: 95-110.

Woolhouse MEJ, Haydon DT, Antia R. 2005. Emerging pathogens: the epidemiology and evolution of species jumps. Trends Ecol Evol 20: 238-244. DOI: 10.1016/j.tree.2005.02.009. 